\title{
The inter-relationship between no harm, equitable and reasonable utilisation and cooperation under international water law
}

\author{
Attila M. Tanzi ${ }^{1}$ \\ Accepted: 10 July 2020 / Published online: 28 September 2020 \\ (c) The Author(s) 2020
}

\begin{abstract}
The chapter addresses the no-harm principle as a core pillar of the international water law regime, and its inter-relationship with the principles of equitable and reasonable utilisation and cooperation. No harm will be described in its harmonised relation to the latter two principles under the "community interest" approach to transboundary watercourses, as enunciated by the Permanent Court of International Justice and later corroborated by the International Court of Justice. Such a harmonised construction of the three-pronged body of international water law will be illustrated as one disproving any alleged priority or, conversely, subservience of either principle with respect to the others. It will also be shown how the same construction emphasises the integration and inter-relationship between the legal principles at hand.
\end{abstract}

Keywords No harm · Equitable and reasonable utilisation · Community interest

\author{
Abbreviations \\ ICJ International Court of Justice \\ PCIJ Permanent Court of International Justice
}

\section{Introductory remarks}

When applying international law to transboundary watercourses, friction may arise between differing interpretations of its basic principles. Generally, lower riparian countries tend to rely on the alleged prevalence of the no-harm principle over the equitable utilisation principle, while upper riparians usually argue for the opposite. ${ }^{1}$ This alleged tension between the two principles is also reflected in the legal literature (Caflisch 1989, $134 \mathrm{ff}$.;

\footnotetext{
1 During the negotiation of the 1997 Convention on the Law of the Non-Navigational Uses of International Watercourses (New York, 21 May 1997; entered into force 17 August 2014; UN Doc. A/51/869), China, Spain, Tanzania, South Africa, India, Bolivia, Colombia expressed support for the prevailing nature of no harm, whilst Czech Republic, Ethiopia, Switzerland and Turkey expressed support for the prevailing nature of equitable utilisation.
}

\footnotetext{
Attila M. Tanzi

attila.tanzi@unibo.it

1 University of Bologna, Bologna, Italy
} 
Utton 1996, 638-639; Salman 2010, 334-335; Tanzi 2017, 1-2; McCaffrey 2019, 98-160), and stems from an assumption that upper riparians are more likely to cause harm to equitable water use. The present chapter illustrates instead how the no-harm rule co-exists harmoniously with the equitable and reasonable utilisation principle.

The chapter will begin by arguing that there can be no competition-neither priority, nor subservience-between the two legal principles at hand. It will then proceed by demonstrating how the two principles reinforce one another, and apply, indistinctly, to both water apportionment and environmental protection issues.

The third section of this chapter will examine the inter-relationship between the noharm and equitable utilisation principles and demonstrate their link to the general principle of cooperation. The inter-relationship will further be analyzed through a reflection on the regime of State liability which is comprised in the no-harm rule, with special regard to compensation as a factor for the equitable balancing of conflicting interests.

Finally, emphasis will be placed on the interaction between the substantive and procedural elements of the no-harm principle. Against this context, the limitations of cooperation will also be considered in relation to compliance with the legal obligations at hand.

In this chapter, the customary rules and principles in question will be analysed through their consolidation in the 1992 UNECE Convention on the Protection and Use of Transboundary Watercourses and International Lakes ("UNECE Water Convention") and the 1997 UN Convention on the Law of the Non-Navigational Uses of International Watercourses ("UN Watercourse Convention"). This codification of customary law in the Conventions at hand has generally been acknowledged in legal literature (McIntyre 2007, 1-2; UNECE 2015a, 11-12; Tanzi 2017, XVI; McCaffrey 2019, 415). It has also been confirmed through the authoritative reference by the ICJ in its 1997 Judgement in the Gabcikovo-Nagymaros case with specific regard to the UN Watercourse Convention. The authority of this statement has further been reinforced through the conclusion of transboundary water agreements across the world that fall within the framework of this Convention.

\section{The systemic and policy untenability of a competitive relation of no harm to equitable and reasonable utilisation}

The leading argument of this chapter is that there can be no competition between the application of the no harm and the equitable and reasonable utilisation principles in transboundary waters. As already indicated, both the no harm and equitable and reasonable utilisation principles have been widely acknowledged as belonging to customary international law (Jiménez de Aréchaga 1960, 334; Arcari and Tanzi 2001, 135; Tanzi 2017, 35; Boisson de Chazournes and Leb 2018, 395; McCaffrey 2019, 469). For this reason, it would be hard to conceive that two customary rules bearing on the same subject-matter could be mutually competitive, let alone conflicting.

Nonetheless, from a policy perspective, there may arise an interpretive difference between the two principles. On the one hand, downstream riparians may rely on the noharm rule possibly arguing that it confers onto them an alleged veto power over planned or existing uses of international watercourses by upper riparians. This attitude stems from a concern that the equitable utilisation principle might reinforce arguments by upper-riparians that legitimise activities that are significantly harmful to lower riparians. However, there is no legal authority which would substantiate this form of advantage by one category of co-riparians over the others. Instead, in international water law transboundary waters 
are configured as shared natural resources based on the principle of community of interest which predicates that co-riparians have equal rights to the use of transboundary watercourses (Caflisch 1989, 58; Tanzi 2017, 3 ff.; McCaffrey 2019, 138 ff.). In other words, there should be no competition between the two legal principles at hand. This logic is corroborated by the UN International Law Commission (ILC) principle of harmonisation, in relation to the issue of the fragmentation of international law (ILC 2006). According to this principle, "when several norms bear on a single issue they should $[\ldots]$ be interpreted so as to give rise to a single set of compatible obligations" (ILC 2006, 178). The following section will illustrate this logic in more detail.

\section{The inter-relationship between the two substantive principles in question}

As described in the previous section, there should be no interpretative difference between the two main principles at hand - no harm and equitable and reasonable utilisation. Instead, they should co-exist according to a harmonious legal relationship that gives rise to a single set of obligations as illustrated through the community of interest principle. As observed by the PCIJ in the River Oder case,

"[T]he community of interest in a navigable river becomes the basis of a common legal right, the essential features of which are the perfect equality of all riparian States in the use of the whole course of the river and the ex-clusion of any preferential privilege of any one riparian State in relation to the others" (PCIJ 1929, 27).

On the one hand, in the 1992 UNECE Convention, the equitable and reasonable use of transboundary waters is set out as one of the appropriate measures that gives effect to the standard obligation "to prevent, control and reduce any transboundary impact" (Article 2 (1) (c) UNECE Water Convention). On the other hand, in the 1997 UN Convention, the noharm rule is laid down in due diligence terms (Article 7 (1) UN Watercourses Convention), but according to a contextual reading of the Convention (Articles 5-7 UN Watercourses Convention) it can be considered as one of the factors which give effect to the equitable utilisation principle (Tanzi 2017, 58). There is thus a mutually reinforcing legal relationship existing between the two principles at hand.

This point will be considered further below with regard to the relationship between the substantive and procedural components of no harm and cooperation.

\subsection{Inter-relationship under the UNECE Water Convention}

Under the 1992 UNECE Water Convention (Article 1 (2) UNECE Water Convention), the no-harm principle represents the main standard of conduct for co-riparians. This does not necessarily imply that the Water Convention gives priority to no harm over equitable utilisation. On the contrary, under the same instrument (Article 2 (2) (c) UNECE Water Convention), it is provided that the parties shall take all appropriate measures to "ensure that transboundary waters are used in a reasonable and equitable way, taking particularly into account their transboundary character, in the case of activities which cause or are likely to cause transboundary impact". Accordingly, this Convention provides for the combined application of both principles as part and parcel of one normative setting. This is in full 
conformity with the systemic consistency of customary law rules on the same subject-matter posited above.

\subsection{Inter-relationship under the UN Watercourses Convention}

In line with the harmonised approach to the two principles at hand, during the preparatory legal work which led to the adoption of the 1997 UN Watercourses Convention, the ILC stressed that "in certain circumstances, 'equitable and reasonable utilization' of an international watercourse may still involve significant harm to another watercourse State" (ILC 1994b, 103). The hypothetical example given by the ILC was that of "a dam which would provide hydroelectric power to hundreds of thousands of people, but which would cause significant harm to a few hundred people in another riparian State whose recreational fishing would be destroyed" (ILC 1994a, 167). Inevitably, a different proportion between harm caused and benefits, or between beneficiaries and victims, would result in an inequitable and unreasonable use of the watercourse. However, still in line with the harmonised approach to the principles in question, under Article 7 of the UN Watercourses Convention a use which causes significant harm to other watercourse States is not necessarily prohibited per se, provided "all the appropriate measures" have been taken to prevent its occurrence. Conversely, a use that causes significant harm, without properly balancing all the equitable utilisation factors, would, thus, amount to a breach of the obligation to take all the appropriate measures for harm prevention purposes. By the same token, such a negligent conduct would breach the legal standards of equitable and reasonable use of transboundary waters.

In sum, from the perspective of the UN Watercourses Convention, the occurrence of significant harm appears as a factor for the determination of the equitable character of a use. This does not mean rendering the no-harm rule subservient to the equitable utilisation principle. It only stresses that the latter is inherent in the former and vice versa. From a systematic reading of the provisions spelling out the equitable utilisation principle and its assessment factors (Articles 5, 6 and $10 \mathrm{UN}$ Watercourses Convention), none of such factors has priority over the others. Laying down the no-harm rule in a separate article only gives a relative priority to the potential, or actual, occurrence of harm over the other factors. Namely, a use that causes significant harm would be presumed to be inequitable, whilst this presumption could still be challenged in relation to other factors, "with special regard being given to the requirements of vital human needs" (Article 10 (2) UN Watercourses Convention).

\section{Cooperative and equitable application of no harm}

The two principles at hand are further inter-related through their connection to cooperation. The relation of both no harm and equitable and reasonable utilisation to cooperation stems from the community of interest principle referred to above. This principle, which draws from the legal and hydrological configuration of transboundary waters as a shared natural resource, provides the rationale behind the inter-relationship between no harm and equitable utilisation. This legal custom stems from international practice existing from long before the codification of international water law: 
"The practice of states, as evidenced in the controversies which have arisen about this matter, seems now to admit that each state concerned has a right to have a river system considered as a whole, and to have its own interests weighed in the balance against those of other states, and that no one state may claim to use the waters in such a way as to cause material injury to the interests of another, or to oppose their use by another state unless this causes material injury to itself" (Brierly 1955, 204).

In order to secure the harmonised inter-relationship between the two principles at hand, cooperation between riparian states is also essential. This is also because the best possible assessment of the appropriate preventive measures in any given case-as well as of the equitable and reasonable character of a given use-will require the involvement of the coriparians potentially affected by a particular use. As observed by the arbitral Tribunal in Lake Lanoux, "[a] state wishing to do that which will affect an international watercourse cannot decide whether another state's interests will be affected; the other state is the sole judge of that". ${ }^{2}$ In that respect, later developments show that the obligation to undertake a transboundary environmental impact assessment of a given activity and to share it with the potentially affected co-riparians is an established standard under contemporary customary law (ICJ 2010, 83 para 204).

Against this legal background, there is also the risk that a potentially affected co-riparian abuses its rights. The UN Watercourses Convention addresses this scenario by providing that when a co-riparian has reasonable grounds to believe that certain planned measures could be significantly harmful to it, it has the right to enter into consultations and negotiations with the planning State (Arcari and Tanzi 2001, 201-210). The latter State is then prevented from going ahead with its project without consultation, while the potentially affected State is, in its turn, prevented from exercising any right of veto indefinitely, without prejudice to its rights under international water law.

As a result, the balance between the two substantive principles at hand reinforces the community of interest principle and reflects the legal configuration of transboundary waters as a shared natural resource (Arcari and Tanzi 2001, 29-30). Accordingly, the concrete application of such a balanced normative setting is left primarily, and ideally, to the agreement of the parties involved precisely because they have a common interest in the optimal development and protection of the transboundary watercourse in question. Thus, it is only natural that the principle of cooperation operates as the key catalyst for the joint application of both substantive principles. When cooperation is successful, international water law can help "provide for processes to promote the identification of common interests and the involvement of all relevant players" (Brunnée and Toope 1994, 59).

Under the UNECE Convention, the establishment of such cooperative regimes is enhanced by the obligation to conclude transboundary watercourses agreements which set up joint water bodies within which to consult and develop further mutually agreeable arrangements on concrete uses and forms of protection of transboundary waters. The participatory and cooperative rationale of the equitable and reasonable utilisation principle has been emphasised by its codification in the UN Watercourses Convention, as follows:

"Watercourse States shall participate in the use, development and protection of an international watercourse in an equitable and reasonable manner. Such participation includes both the right to utilize the watercourse and the duty to cooperate in the

\footnotetext{
${ }^{2}$ Lake Lanoux Arbitration (France v Spain) (1957). United Nations Reports in International Arbitral Awards, 12, 281-317.
} 
protection and development thereof, as provided in the present Convention" (Article 5 (2) UN Watercourses Convention).

The fact that the obligation of equitable participation must be implemented "as provided in the present Convention" singles out the link between the equitable utilisation rule and the procedural provisions of the Convention which give effect to the principle of cooperation. As observed by the ILC, the rationale behind the concept of equitable participation is "cooperation between watercourse States through participation [...] in measures, works and activities aimed at attaining optimal utilization of an international watercourse, consistent with adequate protection thereof" (ILC 1994b, 97). As emphasised by Professor Lammers, the concept of equitable participation

"[M]eans more than the mere duty to co-operate but is an expression of a duty to follow the so-called 'integrated approach', which entails the global consideration of all uses of water, linked to other derivative problems such as nature conservation. ... [It] relates to two kinds of interferences with water - i.e. not only interference caused by human activities (which is characteristic of the principle of equitable utilization) but also interference by nature" (Lammers 1984, 548).

The above being said, insofar as control and protection are essential to the proper maintenance of a watercourse and to the welfare of the river community within its basin, each riparian State is required to adopt appropriate measures individually, irrespective of any cooperation or coordination with co-riparian States. Consequently, the principle of equitable participation enhances the vision of an international watercourse as a "river community" entailing the obligation for riparian states - jointly, or individually — to take action to ensure its protection and control together with its development.

\section{The no-harm rule in relation to the occurrence of harm: the liability regime}

Another inter-relationship to be addressed concerns the legal consequences which derive from the occurrence of 'harm' in transboundary watercourses. This is one of the few areas in which the UN Watercourses Convention provides more normative indications than the UNECE Water Convention. The latter is more detailed in articulating the no-harm principle on the preventive side, by providing elaborate guidance, as well as compulsory institutional cooperation. On the other hand, the UN Watercourses Convention focuses more closely on the legal of consequences of the occurrence of harm.

Article 7 (2) of the UN Watercourses Convention reads as follows:

"Where significant harm nevertheless is caused to another watercourse State, the States whose use causes such harm shall, in the absence of agreement to such use, take all appropriate measures, having due regard for the provisions of articles 5 and 6 , in consultation with the affected State, to eliminate or mitigate such harm and, where appropriate, to discuss the question of compensation".

In essence, the above provision confers onto a State the obligation to take all appropriate measures "to eliminate or mitigate the harm" although it has complied with the requirements of harm prevention. This legal framework coincides with the body of international 
law known as State liability for acts not prohibited by international law (Tanzi 2019). ${ }^{3}$ The UN Watercourses Convention (Articles 5, 6 and 7) reinforces this logic by indicating that elimination or mitigation of the harm occurred despite all appropriate preventive measures having been taken should be considered as a factor for determination of the equitable character of a given use. This is substantiated by Article 7 (2) quoted above insofar as the measures to eliminate, or mitigate, the harm must be adopted "having due regard for the provisions of articles 5 and 6", which spell out the principle of equitable and reasonable utilisation. This language provides a basic term of reference for consultations between the States concerned in order to agree on the equitable and reasonable measures which are appropriate for the elimination or mitigation of the harm.

The above is plainly in line with the UNECE Water Convention with regard to the obligation "to prevent, control and reduce any transboundary impact" (Article 2 (1)).

\subsection{Compensation as a form of State liability under the no-harm rule}

Compensation is generally recognised as a key legal aspect stemming from an international wrong. However, under Article 7 of the UN Watercourses Convention quoted above, compensation is not intended as a consequence of a wrong, nor as an absolute obligation to pay the full loss triggered by the occurrence of transboundary harm (Tanzi 2019). Under the State liability regime in question, compensation is instead associated with the obligation to consult and with a view to balancing equitably the interests of all the States concerned (ILC 1994b, 117).

While Article 7 (2) of the UN Watercourses Convention is primarily envisaged to operate after harm has occurred, its express reference to the equitable and reasonable utilisation principle indicates that compensation may also be provided when a planned activity is expected to cause significant transboundary harm. Here, compensation comes into play in relation to consultations and negotiations on "the possible effects of planned measures on the condition of an international watercourse" (Article 11 UN Watercourses Convention), or on whether the "implementation of planned measures would be inconsistent with the provisions of article 5 or 7" (Article 17 UN Watercourses Convention).

When determining the terms of compensation, States that are likely to be affected by transboundary harm may also contribute to the costs of prevention, as well as of elimination, or mitigation, once the harm has occurred. Compensation, here again, operates as one of the factors involved in the equitable balancing of interests between the co-riparians concerned. This approach is substantiated by age old international practice (Jiménez de Aréchaga 1960, 195). One such example is the landmark Columbia River Treaty of 1961 which provided for the distribution of benefits between the parties, including compensation for the flooding of areas in Canada to be paid in advance.

It is also important to highlight that the form of compensation does not need to be solely financial in nature (Bush 1981, 309). When compensation is not confined to financial mediums, it becomes a means by which to ensure the equitable apportionment of benefits, thus enhancing the interlinkage between no harm and equitable utilisation. This was similarly observed by a German court in the Donaversinkung case,

\footnotetext{
3 Since the present paper is confined to the governmental dimension of the no-harm principle, civil liability considerations before domestic courts are excluded from the scope of the analysis.
} 
"The interests of the States in question must be weighed in an equitable manner one against the other. One must consider not only the absolute injury caused to the neighbouring State, but also the relation of the advantage gained by the one to the injury caused to the other". 4

When determining compensation for harm caused in transboundary watercourses, it is therefore important to balance the differing States' interests and perspectives to ensure equitable and reasonable responses.

\section{Inter-relationships between no harm and cooperation and the interaction between the substantive and procedural law dimension of no harm for purposes of assessing its breach}

In the previous section, it was illustrated how the no-harm principle and the corresponding State liability regime are intertwined with the obligations of cooperation. As pointed out, these are intertwined, through exchanges of data, consultations, joint and concerted action. As observed by the ICJ in Pulp Mills, "it is by co-operating that the States concerned can jointly manage the risks of damage to the environment that might be created by the plans initiated by one or other of them, so as to prevent the damage in question" (ICJ 2010, 49 para 77).

When examining these legal inter-relationships between the principles at hand and their connections to cooperation, there are two main scenarios that can emerge. The first one is directly grounded in law and consists of the circumstance in which the co-riparians concerned engage in a mutually cooperative relationship on one or more projects which are in conflict with the obligations of harm prevention and equitable utilisation. The second scenario is grounded in fact, but is fraught with significant legal consequences. It consists of the circumstance in which cooperation is simply to no avail, due to the lack of willingness to cooperate on the part of co-riparians.

As concerns the first circumstance, it is important to note that the cooperative relationship between the co-riparians does not automatically ensure that the activities undertaken comply with the legal principles under consideration. Cooperation is an important means by which to comply with the obligations of equitable utilisation and harm prevention, but cannot be conflated with an end in itself. The point was reinforced during the Meeting of the Parties to the UNECE Water Convention in 2015 (UNECE 2016). After recalling "that transboundary cooperation is a key principle of the Convention, as it supports the achievement of the Convention's object and purpose" (UNECE 2015b, 8 para 2), it is stressed that, nonetheless, "cooperation per se is not the only objective of the Convention and that the principles of reasonable and equitable use and of prevention, control and reduction of transboundary impact are no less important" (UNECE 2015b, 8 para 3). In other words, cooperation and agreement between co-riparians are not a licence for the infringement of the standards required by harm prevention and equitable and reasonable utilisation.

In the second scenario, the focus is instead on cases where cooperation is not possible due to the lack of good will by one or all of the co-riparians concerned. Given the crucial intersection between individual States' territorial sovereignty and the no-harm rule,

\footnotetext{
4 Donauversinkung case (Wurttemburg and Prussia v. Baden, 1927), in International Law Reports: Annual Digest of Public International Law Cases 1927-1928, p. 158.
} 
however, the standards of no harm are still legally binding on riparian States individually, irrespective of their co-riparians' attitude. That is also to say that lack of cooperation by coriparians cannot justify a breach of no harm through unfettered unilateral discretion. This was corroborated by the ICJ in the Gabčíkovo-Nagymaros case (ICJ 1997, 54 para 78). The Court held Slovakia internationally responsible for the unilateral continuation water works as a reaction to Hungary pulling out of a joint development project on the Danube River

\section{Concluding remarks}

It can be concluded that no harm in combination with the equitable and reasonable utilisation principles produces a framework for joint dispute prevention, management and settlement that facilitates cooperative scenarios. Against this background, two main considerations emerge. The first one regards the argument, advanced by the ILC in its preparatory work of the UN Watercourses Convention quoted above, according to which a significantly harmful use is not automatically inequitable. The second one pertains to the question whether, and if so, to what extent, non-compliance with the procedural obligations of due diligence making up no harm — and thus also equitable utilisation—may amount to a breach of no harm when significant harm does not occur.

As to the argument according to which a significant harm-causing utilisation is not wrongful per se, it is unquestionably conducive to negotiation over planned or existing measures for the user Country. This argument may fail to appeal to the actual or potential victim State. However, it is arguable that the stakes between the origin State and the potentially affected one would be balanced by reversing the burden of proof over the equitable character of a use that causes, or is likely to cause, significant harm. That is to say that, on the one hand, the presumption could be inferred from the substantive rules under consideration that a use that causes significant harm is not permissible, while, on the other, such a presumption may be countered by placing on the origin State the burden, or the power, to prove that a given use is equitable and reasonable on balance with all relevant factors. Such factors would include the offer by the origin State of ways and means to balance the equities at stake, through the distribution of the benefits deriving from planned measures, possibly, together with preventive compensation, redress or mitigation of the harm caused. In its turn, the potential or actual victim State would have the duty to consider such offer in good faith. One may hope that in the longer run the above considerations may win over the ICJ reluctance against the reversal of the burden of proof, at least under the specific circumstances bearing on transboundary natural resources (ICJ 2010, 71 para 164). At least, the occurrence of significant harm, or the risk thereof, should be proven by the riparian claiming it, but compliance with the due diligence standards of prevention should be proven by the origin State. Especially in a risk perspective, the reversal of the burden of proof onto the origin State becomes an opportunity and an incentive for the latter State to bring the harm-causing activity into conformity with the equitable utilisation principle.

As to the second and reverse question whether and, if so, when, non-compliance with the procedural obligations making up the no-harm rule may constitute a breach of such a rule even in the absence of harm, a gradually increasing jurisprudential and scholarly trend has been illustrated which may tip the balance against the ambiguity of the ICJ case law. Namely, the trend in question point towards increasing possibilities for an integrated approach between no harm and equitable and reasonable utilisation. When analysed together, the procedural and substantive legal dimensions of both rules enhance their 
entanglement, both with and without cooperation. The two principles are mutually reinforcing and together form an integrated framework by which to address harm in transboundary watercourses, either in terms of prevention or of the consequences of its occurrence.

Funding Open access funding provided by Alma Mater Studiorum - Università di Bologna within the CRUI-CARE Agreement.

Open Access This article is licensed under a Creative Commons Attribution 4.0 International License, which permits use, sharing, adaptation, distribution and reproduction in any medium or format, as long as you give appropriate credit to the original author(s) and the source, provide a link to the Creative Commons licence, and indicate if changes were made. The images or other third party material in this article are included in the article's Creative Commons licence, unless indicated otherwise in a credit line to the material. If material is not included in the article's Creative Commons licence and your intended use is not permitted by statutory regulation or exceeds the permitted use, you will need to obtain permission directly from the copyright holder. To view a copy of this licence, visit http://creativecommons.org/licenses/by/4.0/.

\section{References}

Arcari, M., \& Tanzi, A. (2001). The United Nations convention on the law of international watercourses: A framework for sharing. London: Kluwer Law International.

Boisson de Chazournes, L., \& Leb, C. (2018). Benefit sharing in international water law: A multi-disciplinary undertaking. In M. Tignino (Ed.), Research handbook on freshwater law and international relations (pp. 391-412). Cheltenham: Edward Elgar.

Brierly, J. L. (1955). The law of nations. Oxford: Clarendon Press.

Brunnée, J., \& Toope, S. J. (1994). Environmental security and freshwater resources: A case for international ecosystem law. Yearbook of International Environmental Law, 5(1), 41-76.

Bush, W. (1981). Compensation and the utilization of international rivers and lakes: The role of compensation in the event of permanent injury to existing uses of water. In R. Zacklin, et al. (Eds.), The legal regime of international rivers and lakes (pp. 309-329). The Hague: Martinus Nijhoff.

Caflisch, L. (1989). Règles générales du droit des cours d'eau internationaux. Collected Courses of the Hague Academy of International Law, 219, 13-225.

ICJ. (1997). Gabčíkovo-Nagymaros Project (Hungary/Slovakia). ICJ Reports, 7-84.

ICJ. (2010). Pulp Mills on the River Uruguay (Argentina v Uruguay). ICJ Reports, 14-107.

ILC. (1994a). Yearbook of the international law commission (Vol. 1). New York: United Nations.

ILC. (1994b). Yearbook of the international law commission (Vol. 2(2)). New York: United Nations.

ILC (2006). Conclusions of the work of the study group on the fragmentation of international law: Difficulties arising from the diversification and expansion of international law. Yearbook of the International Law Commission, vol II(2), 177-184.

Jiménez de Aréchaga, E. (1960). International legal rules governing use of waters from international watercourses. Inter-American Law Review, 2(2), 329-339.

Lammers, J. G. (1984). Pollution of international watercourses: Search for substantive rules and principles of law. The Hague and Boston: Martinus Nijhoff.

McCaffrey, S. (2019). The law of international watercourses. Oxford: Oxford University Press.

McIntyre, O. (2007). Environmental protection of international watercourses under international law. Farnham: Ashgate Publishing.

PCIJ. (1929). Case relating to the Territorial Jurisdiction of the International Commission of the River Oder (United Kingdom, Czechoslovakia, Denmark, France Germany and Sweden v. Poland). PCIJ Report Series A No. 23.

Salman, S. M. A. (2010). The doctrine of equitable and reasonable utilization of international water and its application under international watercourses law. Water International, 35(4), 350-364.

Tanzi, A. (2017). The consolidation of international water law: A comparative analysis of the UN and UNECE water conventions. Napoli: Editoriale scientifica.

Tanzi, A. (2019). State liability for lawful acts. Max Planck Encyclopedia of Public International Law. https ://opil.ouplaw.com/view/10.1093/law:epil/9780199231690/law-9780199231690-e1065?rskey=p8C4F T\&result $=3 \&$ prd $=$ MPIL . 
UNECE. (2015a), The Economic Commission for Europe Water Convention and the United Nations Watercourses Convention the Economic Commission for Europe Water Convention and the United Nations Watercourses Convention An analysis of their harmonized contribution to international water law. An analysis of their harmonized contribution to international water law. UN Doc. ECE/MP.WAT/42.

UNECE. (2015b). Report of the implementation committee to the meeting of the parties. UN Doc. ECE/ MP.WAT/2015/5.

UNECE (2016). Decision VII/1. General issues of implementation. UN Doc. ECE/MP.WAT/49/Add.2.

Utton, A. E. (1996). Which rule should prevail in international water disputes: That of reasonableness or that of no-harm? Natural Resources Journal, 36(3), 635-641.

Publisher's Note Springer Nature remains neutral with regard to jurisdictional claims in published maps and institutional affiliations. 